iolises

\title{
Investigation of Child Assessment in Preschool Education Using Nominal Focus Group Technique
}

\section{Research Article}

\author{
Ali Ibrahim Can GOZUM"1 ${ }^{1}$, Sabri GUNGOR², Senay Ozen ALTINKAYNAK³ \\ ${ }^{1}$ Kafkas University, Dede Korkut Faculty of Education, Department of Early Child Education, Kars, Turkey, ORCID: 0000-0002-7765-4403 \\ ${ }^{2}$ Kafkas University, Dede Korkut Faculty of Education, Department of Early Child Education, Kars, Turkey, ORCID: 0000- 0002-0254-1885 \\ ${ }^{3}$ Kafkas University, Dede Korkut Faculty of Education, Department of Early Child Education, Kars, Turkey, ORCID: 0000- 0002-6614-4168
}

To cite this article: Gozum, A. I. C., \& Gungor, S., \& Altinkaynak, S. O. (2021). Investigation of child assessment in preschool education using nominal focus group technique, International Online Journal of Educational Sciences, 13(1), 238-257.

\begin{tabular}{|c|c|}
\hline ARTICLE INFO & ABSTRACT \\
\hline Article History: & $\begin{array}{l}\text { This study aims to determine preschool teachers' knowledge of recognition and evaluation } \\
\text { methods and techniques in early childhood, their use of these methods and techniques, and the }\end{array}$ \\
\hline Received: 24.09 .2020 & $\begin{array}{l}\text { problems they encounter in practice. Given its qualitative research nature, this study was } \\
\text { conducted using case study design. Three data collection tools were used to collect data in the }\end{array}$ \\
\hline Available online: & study. The personal information form was used to record the demographic characteristics of the \\
\hline 18.02.2021 & $\begin{array}{l}\text { participants and the relevant literature was scanned to find the focus group discussion form and } \\
\text { nominal focus group discussion forms used for the focus group and nominal focus group } \\
\text { discussions. Data for the study were collected by combining the focus group and nominal focus } \\
\text { groups techniques. The study group consists of } 10 \text { preschool teachers working in the eastern } \\
\text { Anatolia Region of Turkey. It was determined that preschool teachers are aware of the meaning } \\
\text { and significance of child assessment, but lack the knowledge and skills to plan and implement } \\
\text { it. }\end{array}$ \\
\hline
\end{tabular}

CC 2021 IOJES. All rights reserved

Keywords:

Evaluation of the child, preschool education, preschool teacher, focus group technique, nominal focus group technique

\section{Introduction}

Preschool children continue to develop at a rapid pace. The developmental indicators of children who are developing normally follow a specific order. However, there may be individual differences in the developmental indicators of children based on hereditary, personality, or environmental characteristics.

\footnotetext{
*Presented as an oral presentation at $5^{\text {th }}$ International Eurasian Educational Research Congress, Antalya, Turkey in 2-5 May 2017. ${ }^{1}$ Corresponding author's address: Kafkas Üniversitesi Eğitim Fakültesi

e-mail: a_ibrahimcan@hotmail.com

DOI: https://doi.org/10.15345/iojes.2021.01.016
} 
Accordingly, children' personality traits, interests, needs, developmental characteristics, learning speed, and styles differ from each other. To support the development of preschool children and provide them with an effective education, information needs to be collected about children's developmental characteristics, their interests, needs, abilities, and environmental conditions (Berk \& Meyers, 2015; Kutlu \& Kaya, 2016; McAfee, Leong, \& Bodrova, 2015). If the process of collecting information about the child is considered a developmental process, then every stage of the process is critical. Differences in behavior and skills may be observed depending on the child's age and maturity. The process of collecting information about the changes and developmental differences that occur in a child is called developmental assessment (Gander \& Gardiner, 1995; Mindes, 2003). In this context, the assessment of preschool children may be expressed as the continual collection of information regarding their learning and development, making the correct instructional decisions based on this information, and interpreting the process (Bredekamp, 2014, p. 345).

Assessment in the preschool period is the process of collecting, recording, and interpreting information to recognize children and evaluate their development. In this process, the children are given standard tests and observed, what they produce is recorded, teacher-family interviews are conducted, and the development of the child is interpreted by considering individual and environmental factors (Ariasian, 1994; Harlen, Gipps, Broadfoot, \& Nuttall, 1992).In the preschool period, children develop quickly and their learning styles differ. Due to these differences, children's development should be assessed systematically and within the teaching process. Preschool education and teacher competencies are very important for assessing children's development and learning (Bredekamp, 2014).

Considering both the speed of their child's development and individual differences, child assessment is difficult and requires expertise. This is because growth, neural maturation, hereditary characteristics, personality, and the environment conditions where the child lives all affect development in the early years of childhood. The child's development and changes directly affect the assessment norms (Ausubel \& Sullivan, 1970). Considering the rapid change in growth and development in the first years of life, the environmental factors affecting this change, and the impact this period has on children's personalities and achievements, it is essential that children are identified and assessed with all their characteristics in the preschool period (Gober, 2002).

Due to the developmental characteristics of preschool children, alternative assessment methods are used instead of traditional assessment methods. When children's developmental needs, interest in learning, and needs are identified using these assessment methods, a learning environment that is suitable for them can be prepared and activities implemented (Bowman, Donovan, \& Burns, 2001; Dunphy, 2010). Since the developmental assessment of preschool children is done in an educational environment, the education program to be applied to children is an integral part of the assessment.

In Turkey, the 2013 Preschool Education Program prepared by the Ministry of National Education (MEB) is applied. Assessment in the Preschool Education Program is not result-oriented but process-oriented. Instant assessments are not appropriate due to differences in children's development speed and learning styles. Therefore, the education program stresses that assessment should be multi-aspectual. The child's development and learning are assessed in connection with the program to be applied by the teacher. Therefore, in the 2013 preschool education program, assessment is along child, teacher, and program lines. The results of assessments for child, teacher, and program can be interpreted for each other. Education plans are prepared on the strength of these assessments (Mesleki Eğitim ve Öğretim Sisteminin Güçlendirilmesi Projesi [MEGEP], 2015). According to the preschool education program, child assessment records children's knowledge, skills, attitudes, and habits by developmental areas using the "Development Observation Form" and the "Development Report" (Milli Eğitim Bakanlığı [MEB], 2013, p.56). 
Knowing the children is important. Knowing the developmental characteristics of children helps identify their strengths and the areas where they need assistance and helps in formulating effective and highquality education programs that can meet their needs. The step taken to get to know the children is a solid start. It forms the foundation for selecting learning methods and tools appropriate to the children's characteristics and thus providing them with an effective and high-quality learning environment. It ensures that children's special needs, which are powerful and open to development, are recognized, supported, and directed at an early age. Creating opportunities for children to get to know themselves improves their individual and social awareness. Knowing and assessing children at an early age make it possible to measure progress or deviation in their development. Thus, it is possible as a professional to provide families with reliable guidance and information regarding their child (MEB, 2011).

As they are responsible for children's education, the task of assessing children in the preschool period falls to the teachers. Teachers are expected to know both child development and identification techniques and how to use them (McAfee \& Leong, 2015). In addition, the United Nations Convention on the Rights of the Child places emphasis on assessing, supporting, following up, and guiding children when necessary (Akyüz, 2000). In this regard, it can be said that preschool teachers, as defenders of children's rights, undertake the critical task of assessing and supporting children's development.

When teachers with the technical knowledge of child assessment act in accordance with the assessment objectives, this directly affects whether or not the goals of the educational process are met. This being the case, when the goals of child assessment are examined, we find that it means determining the child's developmental process and current developmental potential, evaluating the degree to which the goals have been met after the planned educational activities have been implemented, revising the education program according to the child's needs and the educational objectives, and making best use of the educational environment according to the child's needs (Snow \& Van Hemel, 2008). In addition, the goal in identifying special needs children during child assessment is to take the necessary measures and consult with the relevant experts by reporting on the child's development. (McAfee \& Leong, 2015). Teachers who assess children in accordance with predetermined goals also assess the educational programs given to the children in light of the information they have gathered. Depending on the outcome of these assessments, the envisaged requirements can be included in the education program after identifying the children either individually or in groups (Shaughnessy \& Greathouse, 1997). Accordingly, child assessment provides information regarding developmental delays in normally developing children or for early intervention and special education needs if there are developmental problems (Telzrow, 1991).

According to Allen and Cowdery (2009), since teachers spend a lot of time with children during the day, they have many opportunities to assess their progress or deviations in their development. Therefore, teachers are expected to have received training in recognition and assessment so as to be able to plan activities that maximize development in the child following as a result of recognition and assessment.

Teachers undertake a key role in the qualitative recognition and assessment of preschool children, and so identifying what they know about this, their practices, and the problems they encounter during this process is crucial in terms of formulating pre-service educational programs for teachers, revising their work while inservice, and taking the necessary measures. In this regard, this study aims to identify what preschool teachers know about the methods and techniques of recognition and assessment in early childhood, their use of these methods and techniques, and the problems they encounter in practice. 


\section{Methodology}

\section{Research Design}

Research design is a case study defined as revealing the details of a group or event then examining and analyzing them (Merriam, 2013). Case studies are a form of research design in which a program, event or activity, process, or one or more individuals are examined thoroughly (Stake, 1995; Yin, 2009). The case identified in this study is the focus group and the nominal group consisting of 10 people selected with the goal of determining the knowledge and practices of preschool teachers with respect to developmental assessment in children in the early childhood period. Two qualitative research techniques were used in the study by combining the techniques for focus group discussions and nominal group discussions in the group in which the case study was conducted.

Figure 1 shows the qualitative data collected in the study by using the focus group discussion technique used on the study's focus group. The qualitative data obtained are listed as items under specific themes by coding them using the document analysis technique. The items obtained were discussed again by the nominal focus group and the order of importance for listing the items was determined. The study's methodological process consists of a combination of the focus group and nominal focus group techniques. A research report was drawn up combining the data obtained using the focus group and nominal focus group discussion techniques as a result of ordering, associating, and elaborating the items from the nominal focus group discussion and the quotes taken verbatim from the focus group discussion. In this context, the focus group and nominal group techniques at the center of the study and their reporting are explained below. The information about the combination process and output of the discussion techniques used in the study is given in figure 1.

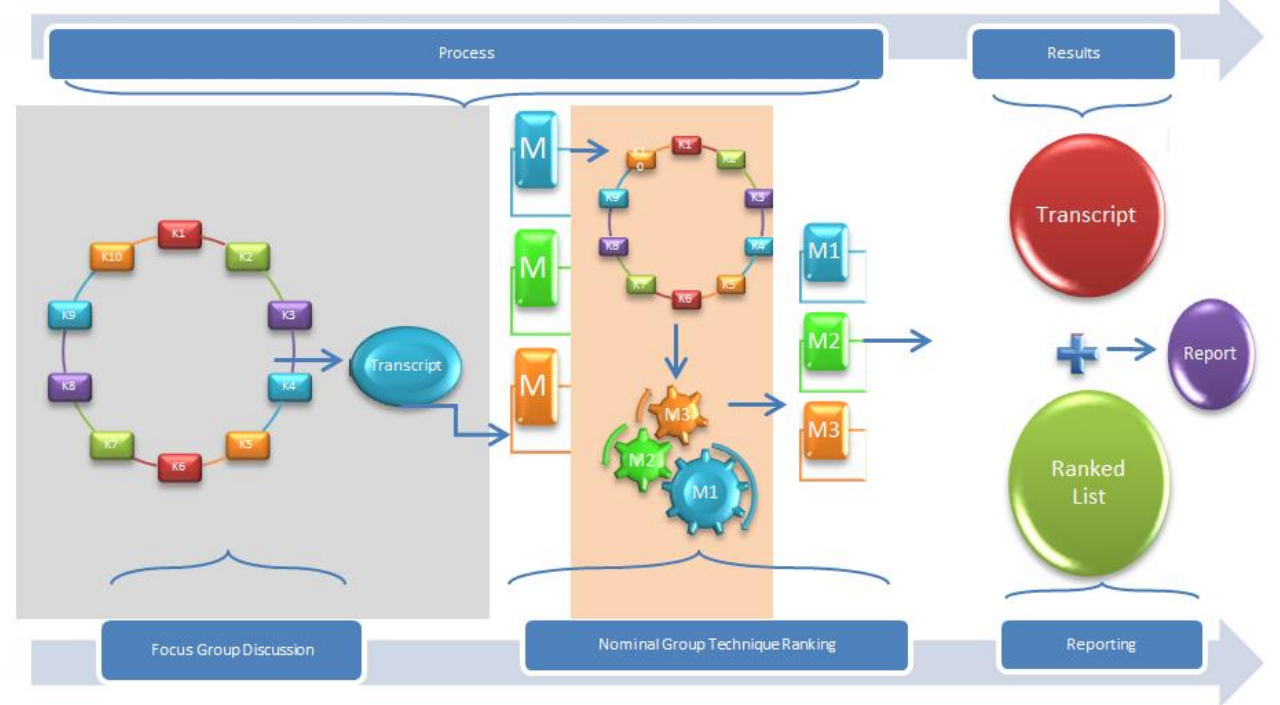

Figure 1. Combination of Focus Group Technique and Nominal Focus Group Technique

Focus Group Discussion Technique was developed from the individual discussion technique based on open-ended questions. Focus group discussion is the process of brainstorming, in-depth information acquisition, and discovery of participants' perceptions of topics given to a small group. In this process, it is defined as a carefully planned discussion environment where the participants can voice their ideas objectively (Bowling, 2002; Kruger, 1994; Wilson, 1997).In this study, the focus group discussion began by discussing the teachers' views on the developmental assessment of early childhood children. This being so, the focus group discussion can be described as a series of planned discussions to illicit teachers' thoughts (Krueger and Casey, 2009). The focus group discussion leader in this study is experienced in focus group discussions. The focus group leader tried to obtain objective opinions from the participants during the focus group discussion. A 
downside of focus group discussions is that the participants influence each other's ideas and are unable to produce concepts, so efforts were made to prevent the leader from directing the answers when the session leader asked questions (Edmunds, 2000).

Nominal Focus Group Discussion Technique is a structured process of arriving at a consensus through oneon-one discussion (Varga-Atkins \& McIsaac, 2011). Nominal focus group technique is a technique applied to get the opinions of every participant especially in studies with many people (MacPhail, 2001). In the nominal focus group technique, participants present their opinions in writing, not verbally. By using this technique, the participants are not able to influence one another as a group and instead express themselves as individuals. This way ensures that every participant's opinion is obtained. Ideas obtained individually are written in a common place to be displayed for the whole group to see. The group discusses the situations that are written in the common place to place them in order. The group is expected to reach a consensus to place the items discussed in order. The points are listed in order of importance following discussions in which participants' individual opinions are transformed into the group's joint opinion (Varga-Atkins, McIsaac, \& Willis, 2017).

Reporting: The process of obtaining the participants' opinions of the research topic by analyzing the data obtained as a result of the focus group discussion. At the end of the nominal focus group discussion, the order of importance of the points relating to the topic under discussion is determined. The points obtained in order of importance are combined with the quotes taken from the group's expressed opinions, and the report is made (Varga-Atkins, McIsaac, \& Willis, 2017).

\section{Study group}

The study group consists of 10 preschool teachers working in an official independent kindergarten affiliated with the eastern Anatolia Region of Turkey's Provincial Directorate of National Education. When forming the study group, the maximum variation sampling technique was used. The aim of maximum variation sampling is to obtain the most information from the participants; therefore, the characteristics of the participants should be as varied as the active cases relating to the research question (Neuman \& Robson, 2014). In this context, the study group displays maximum variation in terms of having graduated from different universities, being of different seniority, and having taught children of different ages. The variation for the study group is given in Table 1.

Table 1. Demographic characteristics of the study group

\begin{tabular}{lcccc}
\hline Code-Gender & Age & Year of Seniority & Period of service at this school & Education age group \\
\hline K1-Female & 44 & 8 & 8 & 5 \\
\hline K2-Female & 46 & 20 & 3 & 4 \\
\hline K3-Female & 29 & 9 & 8 & 5 \\
\hline K4-Female & 32 & 10 & 3 & 5 \\
\hline K5-Female & 28 & 6 & 1 & 3 \\
\hline K6-Female & 26 & 2 & 2 & 4 \\
\hline K7- Male & 24 & 3 & 2 & 3 \\
\hline K8-Female & 34 & 6 & 2 & 4 \\
\hline K9-Female & 32 & 10 & 2 & 3 \\
\hline K10Female & 34 & 9 & 3 & 5 \\
\hline
\end{tabular}

When Table 1 is examined, it can be seen that nine of the teachers participating in the study are female and one is male. The teachers in the study range between 24 and 44 years of age. The teachers' professional seniority varies between 2 and 20 years. The children in the teachers' classes are aged 3, 4, and 5 years old. 


\section{Data collection tools}

Three data collection tools were used to collect data in the study. A personal information form was utilized to record the participants' demographic characteristics. A draft focus group discussion form to gather data for the study during the focus group discussion was created by scanning the literature. The draft form was sent to 5 academics who had made scientific studies on child recognition and assessment techniques and child development in preschool education. Field experts were asked to comment on the appropriateness of the questions on the interview form. The interview questions were assessed as "appropriate", "not appropriate," and "suggestions for correction." All of the field experts stated that the questions on the interview form were appropriate. A trial interview was conducted with two teachers to determine whether or not the interview form was suitable in terms of understandability. The teachers were asked to comment on how understandable the questions were. The teachers stated that the questions were understandable. As a result of the trial run, the focus group discussion form, consisting of 11 questions, was finalized. For the study, a nominal focus group discussion form was prepared for the nominal focus group discussion consisting of new questions including the 12 questions derived as a result of transcripts made of the focus group discussion. The questions in the Nominal Focus Group interview form were presented in the findings.

\section{Data collection process}

The data for the focus group discussion were collected in the schools where the teachers worked. During the data collection process, the meeting was held at a time when the teachers were not working and in an environment where the discussion would not be interrupted (meeting room). Teachers were briefed on the discussion process and questions about the study were asked. The teachers were told that the discussions would be recorded and permission was obtained for these recordings to be made. The focus group discussion was conducted under the leadership of the researcher with experience in focus group discussions. One other researcher was present during the discussions and took notes to determine the questions for the nominal focus group. During the discussion, the participants were addressed using the codes (K1, K2, etc.) written on badges attached to their lapels. The discussion lasted 1 hour 59 minutes 37 seconds. After the focus group discussion, data were collected and the nominal focus group discussions began. During the nominal focus group discussions, the nominal group participants' opinions were noted on the nominal discussion form. Once the written work was complete, the items on every participant's discussion form were written question by question on a board that all participants could see and the items were examined. The items relating to the content of the questions were discussed in group and ranked in the order that the group agreed on. The researchers recorded the rankings in their notebooks.

\section{Data analysis}

The analysis of the data obtained in the study consists of a descriptive analysis of the ranking of the answers given to the related questions following the nominal group discussion and the transcription of the recordings made during the focus group discussion. When conducting descriptive analysis, a framework is created for analysis, data is processed according to the thematic framework created, findings consisting of the processed data are identified, and the findings are then interpreted (Yıldırım \& Şimşek, 2013). In this study, a thematic framework for the developmental assessment of children was created. Thematic framework is explained in figure 2 . 


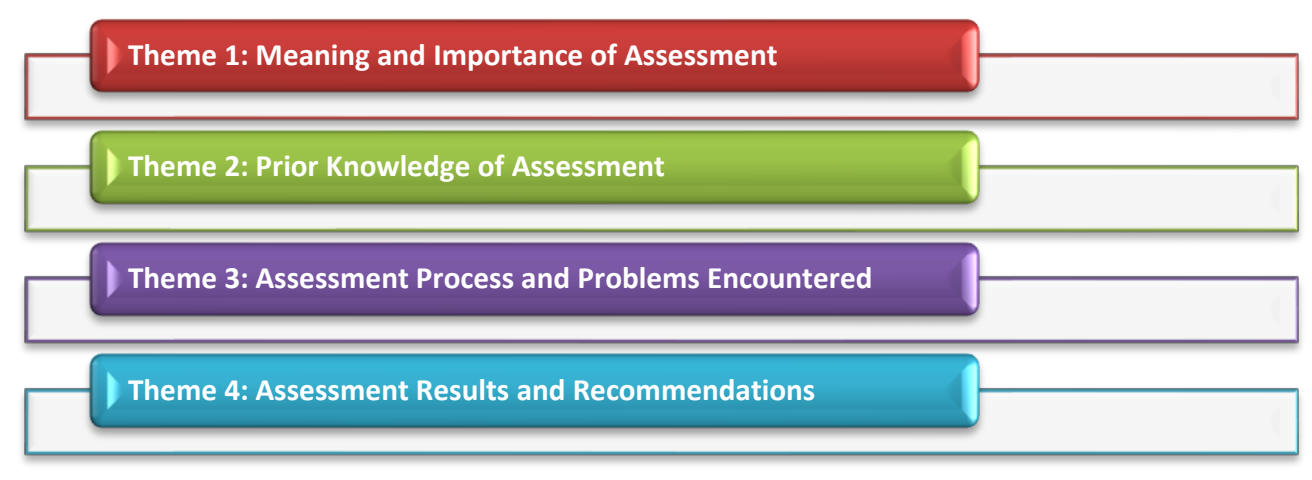

Figure 2. Thematic framework of the research

According to Figure 2, the codes obtained after both the focus group discussion and the nominal focus group discussion were placed within the thematic framework. After the codes were processed by theme, the focus group and nominal focus group data and the findings were identified. Once the findings became a meaningful whole, detailed information relating to the developmental assessment of children and the ranking for the items were identified and interpreted.

\section{Validity and reliability}

To increase this study's validity and reliability, it includes information on the validity and reliability of the tools used to collect the data used in the study, the data collection process, and the analysis of the data. In addition, information on the purpose of the research design used in the study is given below along with explanations to increase the validity and reliability of the data analysis. (Yıldırım \& Şimşek, 2013; Merriam, 2013).

Research design: The purpose of combining the focus group and nominal focus group discussions is to increase the validity of the study by applying the nominal focus group technique to account for individual points of view influencing the debate in the focus group discussion due to shy or quiet personality types. In addition, since the list of items obtained as a result of the nominal focus group technique is made by the participants, it provides participant objectivity in the validity and reliability of the data analysis by reducing bias on the part of the researchers who coded and categorized the data (Wilson, 1997).

Data Collection Tools: A semi-structured discussion form was created for use in this study by scanning the literature. The discussion form for the study was presented to five experts and their opinions were sought by asking them on a form to respond "Suitable," "Not suitable," or "Suggestions for fixing" as appropriate. Then, the opinions and suggestions of the experts were examined. The experts stated that all of the items on the interview form were appropriate. Accordingly, the content validity of the interview form was ensured based on expert opinion. A language expert was asked to provide opinion on clarity and comprehensibility and then a test was made for clarity and comprehensibility after the interview held with two teachers. The teachers said that every question on the measurement form was clear and understandable. The interview questions are shown under the "Findings of the Study" subheading.

Analysis of the data: Miles and Huber's (1994) formula [Reliability=Consensus/ (Consensus+Disagreement)] was used to determine the reliability of data analysis based on the coding, themefinding, and categorizing carried out by the researchers. It was determined that the coefficient of fit for the codes under the relevant themes in 0.95 . 


\section{Findings}

The findings obtained in this part of the study are presented in four themes: the meaning and importance of assessment, the level of prior knowledge of assessment, the assessment process and the problems encountered, and the results of the assessment and recommendations.

\section{Theme-1: Meaning and Importance of Assessment}

This theme includes questions to determine what preschool teachers know about the definition and importance of assessment.

\section{What do you think assessment in the preschool period is?}

Table 1 shows the items taken from the nominal group under the theme "What for you is assessment in the preschool period?" obtained from the text that was transcribed after the focus group discussions. For the nominal group evaluation, the participants first wrote their individual answers to the questions put to them. The participants then debated the items as a group and identified the ranking order they all agreed on. The ranking order for the items as determined by nominal group debate is given in Table 2 .

Table 2. Ranking for items relating to assessment in the preschool period

1. Multi-aspect (child, teacher, parent) assessment

2. Determining the children's development levels

3. Monitoring of personality development

4. Teacher self-assessment

5. Activity assessment

6. Determining achievement status

7. Determining children's competencies

8. Using different assessment tools

According to Table 2, the most important and most agreed on item in the nominal group evaluation is "Multi-aspect (child, teacher, parent) assessment." One teacher's opinion identified in the focus group discussion is quoted verbatim below.

I don't think it's right to assess only the child; at this time teachers, parents, the situation, the process; all should be assessed.(K6)

\section{What is the importance of assessment in the preschool period?}

Table 3 shows the items that the participants all agreed on during nominal group evaluation under the theme "The importance of assessment in the preschool period" taken from the text transcribed after the focus group discussion. The ranking order for items relating to the importance of evaluation in the preschool period is shown.

Table 3. Ranking for items relating to the importance of assessment in the preschool period

1. Determining the children's development levels

2. Being decided in this critical period

3. Parents and teachers need to be aware of the child's developmental level.

4. Presenting the opportunity to inform/share with the family

5. Discovering skills

6. Ensuring that the teacher instills correct attitudes and behaviors

7. Making the teacher see their deficiencies

8. Showing child's personality development

9. Preparing activities appropriate to the children's development level

10. Determining behavior problems

11. To see and correct character disorders 
According to Table 3, the most important and most agreed on item in the nominal group evaluation appears to be "Determining the children's development levels." However, "Being decisive in this critical period" and "Parent and teachers need to be aware of the child's developmental level" were also considered important. Verbatim quotes taken from the teachers are given below.

What can we add to the child by seeing what stage he is at, or if there are any negative traits, how can we change them? How can we nip problems or errors in the bud; how can we improve on the positive? Assessment is important in that it provides illumination for us.(K9)

First of all, I think assessment is important for the parents because their perspectives are quite different. Parents always see the same shape and may not be aware, or they can blow something out of proportion pretending they are aware. So, I think that in assessment it is important for parents and teachers to realize where the child is and that this is very important for subsequent education.(K4)

\section{Theme 2: Prior Knowledge of Assessment}

This theme included questions to determine what training the preschool teachers had in child assessment and what they knew about the methods of assessment in the preschool education program.

3. Did you take classes in child assessment during your undergraduate education? Have you received any inservice training relating to child assessment at any time in your professional life? Do you consider the training you received to be adequate? If you think your training was inadequate, what are the reasons why?

Most of the teachers participating in the study $(n=6)$ stated that they did not take courses to evaluate children during their undergraduate period; all of them did not receive in-service training on evaluating children, and the the overwhelming majority $(n=9)$ stated that the measurement and evaluation training they received during their undergraduate period was inadequate to evaluate children.

Table 4 gives the rankings for the items according to the participants in the nominal group discussion under the theme "Causes of inadequate child assessment training for preschool teachers" identified after the focus group discussion.

Table 4. Ranking for causes of inadequate child assessment training

1. No in-service training or limited training

2. Lack of courses on this subject in the education program

3.Lectures given by faculty members who are not field experts

4. Lessons are very different from practice

5. In-service training contents are not application-oriented

6. In-service training takes place out of the province

7. In-service training is not provided by experts.

8. In-service training given as procedure

According to Table 4, the most important and most agreed on item in the nominal group evaluation is "Lack of in-service training or limited number." Verbatim quotes taken from teachers' comments with respect to the item rankings agreed on as a result of the nominal group discussion are given below.

I worked in the metropolitan city for four years; no correspondence came to our school. Nothing

that said we have some seminars on assessment, you will attend or attend if you can.(K10)

\section{What do you think about the assessment methods/tools in the preschool education program?}

The vast majority $(n=7)$ of the teachers in the study stated that they did not have sufficient knowledge about the assessment methods and tools in the preschool education program. 
Table 5 gives the rankings of items taken from the transcripts of the focus group discussion under the theme "Assessment tools in preschool education programs" and after the assessment made by the nominal group participants under the same theme.

Table 5. Ranking for items relating to assessment in the preschool education program

1. Only remains on paper

2. I think it is necessary and important

3. It takes a lot of time to use

4. It is not used for its purpose

5. It does not reflect reality

6. Assessment tools are inadequate

According to Table 5, the most important and most agreed on item in the nominal group evaluation is "Only remains on paper." Verbatim quotes taken from teachers' comments with respect to the item rankings agreed on as a result of the nominal group discussion are given below.

I fill in the observation forms mandated by the curriculum. I don't believe that we fill in the development reports very well, and I think it's because they restrict us there. They want us to use a professional language and when I write it, I don't think that I'm going by rote or that I'm using an assessment tool. I don't think I'm very knowledgeable.(K3)

\section{Theme 3: Assessment process and problems encountered}

Questions about why preschool teachers do assessment work, the tools they used for this purpose, the principles they observed, and the problems they encountered were asked under the theme "Assessment process and problems encountered."

\section{What assessment techniques do you use? Please indicate why you use this technique?}

Table 6 gives the rankings for the items identified by the participants relating to nominal group evaluation under the theme "Assessment techniques used in preschool education" identified in the focus group discussion.

Table 6. Ranking for the items relating to assessment techniques used in preschool education

1. Observation

2. Developmental observation form

3. Developmental observation report

4. Video recordings

5. Correspondence (such as letter, diary)

6. Portfolios

According to Table 6, at the end of the nominal group evaluation, the most important and most agreed on item among the assessment techniques in preschool education is "Observation." Verbatim quotes taken from teachers' comments with respect to the item rankings agreed on as a result of the nominal group discussion are given below.

There are progress observation reports in the program and we fill them in. This is what is requested from us, but we have personal observation reports that we have, my friend prints a letter, I have forms that I send to the parents saying if he child can do something or not; I send them at the beginning of year and in the middle so they can see where the child is at; apart from that, are the others enough for us? No. That's all I know.(K4) 
Teachers who stated why they use this (observation) technique gave answers including: can be carried out at any time with no waiting; do not require tools or instruments, seen as the most correct and practical technique in daily life, allow for immediate intervention, allow for rapid feedback, easy to implement, and allows the child to be observed in a natural environment.

\section{When during teaching do you carry out assessment?}

Table 7 gives the ranking for the items identified by the participants relating to the nominal group discussion under the theme "When during teaching is assessment made?" and those identified by the focus group discussion under the same theme.

Table 7. Ranking for items relating to when during teaching assessment should be made

1. At the end of the month

2. At the end of the semester

3. During the activity

4. At the end of the activity

5. At the end of the day

According to Table 7, the most important and most agreed on item in the nominal group evaluation is "At the end of the month." Verbatim quotes taken from teachers' comments with respect to the item rankings agreed on as a result of the nominal group discussion are given below.

... I usually write my observation reports at once at the end of the month, after the 20th to 25th, we observe their total development and assess the report every month in a report card. In the end we have given their report cards and this is valid for both semesters, making our assessments monthly like this.(K2)

When asked why they chose that particular time (end of month), the teachers listed such reasons as setting the next goal, to see if the methods and techniques used were appropriate, because assessment requires a process, and because it is required in the program.

\section{What factors do you consider when assessing the child?}

Table 8 gives the ranking for the items determined by the focus group discussion under the theme "Factors considered when assessing the child" and by the participants following the nominal group evaluation under the same theme.

Table 8. Ranking for factors considered when assessing the child

\begin{tabular}{l}
\hline 1. Family characteristics (education, socioeconomic situation, family relations) \\
\hline 2. Orientation toward individual differences \\
\hline 3. Child's psychological and sociological status \\
\hline 4. Various (includes different areas of development such as cognitive, affective, etc.) \\
\hline 5. Environment and time
\end{tabular}

According to Table 8, the most important and most agreed item in the nominal group evaluation is "Family characteristics (education, socioeconomic situation, family relations)." Verbatim quotes taken from teachers' comments with respect to the item rankings agreed on as a result of the nominal group discussion are given below.

The child's upbringing, his family's profession, and the environment in which he grew up. I would definitely talk to his family and consider their point of view.(K3) 


\section{What are the most common problems encountered in the assessment process?}

With the focus group meeting, the theme "The most common problems in the assessment process" was determined.

Table 9. Ranking for items relating to problems encountered in assessment

\begin{tabular}{l}
\hline 1. High number of children \\
2. Problems with sharing and using the results (problems with the family) \\
\hline 3. Failure to ensure cooperation with the school administrators \\
\hline 4. Not having enough information \\
\hline 5. The importance of assessment is not understood \\
6. Having to fill in the forms \\
\hline 7. Problems in finding the time
\end{tabular}

According to Table 9, the most important and most agreed on item in the nominal group evaluation is "The number of children." However, "Problems with sharing and using the results (problems with the family)" stands out as another expression considered important by the participants.

... I cannot apply the same thing to 20 children in the same class, in a small classroom, and this makes me feel inadequate.(K6)

We have problems with this issue; we always have problems with parents. We can't explain things, can't convince them. They think we're fobbing them off; I mean they see us as babysitters and they let it go saying it's just a phase and the child will grow out of it.(K10)

\section{For what purpose do you assess?}

Table 10 gives the ranking for items determined by the focus group discussion under the theme "For what purpose the assessment was made?" and for the item ranking that the participants agreed on following the nominal group discussion.

Table 10. Ranking for the items relating to purpose of assessment

1. Supporting the child's development

2. Determining the child's level of development

3. Self-evaluation

4. To evaluate the activities

5. To improve myself and my teaching practices

According to Table 10, the most important and most agreed on item in the nominal group evaluation is "Support the child's development." Verbatim quotes taken from teachers' comments with respect to the item rankings agreed on as a result of the nominal group discussion are given below.

I mean, speaking for myself, can I be effective in terms of supporting the child's psychological, social, and every other form of development? How prepared is the child? This is my goal and how effective I can be and how effective I can be after that. We use it to determine new goals, new methods, and to find out the child's stage of development.(K7)

\section{Theme 4: Assessment Results and Recommendations}

In the fourth theme of the study it was determined with whom the assessment results are shared and the participants made suggestions as to how the process could be more effective. 


\section{With whom do you share assessment results?}

Table 11 gives the ranking for the items identified by the focus group discussion under the theme "With whom do you share assessment results?" and for those identified by the participants for the nominal group evaluation under the same theme.

Table 11. Ranking for the items relating to whom assessment results are shared with

\begin{tabular}{l}
\hline 1. Family \\
\hline 2. School administrators \\
\hline 3. Other teachers \\
\hline 4. Special education teacher \\
\hline
\end{tabular}

According to Table 11, the most important and fully agreed on item in the nominal group evaluation is "Family." From the verbatim quotes taken from the teachers with respect to the ranked items agreed on following the nominal group discussion, it was determined that teachers experience anxiety when sharing assessment results with families. Verbatim quotes from the teachers with respect to this situation are given below.

...I've experienced something like this. I share the results with the parents. However, what matters is how the parents are going to react. How are the parents going to react, should I share this information or not? That's what goes through my mind.(K6)

\section{Is attention ever paid to assessment results?}

As for whether or not attention is paid to the assessment results, half the teachers said it was and the other half said it was not. In this context, it is noteworthy that the majority of the teachers $(n=7)$ when asked if the results were ever used functionally said that they were not used functionally.

Table 12 gives the rankings for the items identified by the focus group discussion under the theme "Teachers who state that assessment results are not used functionally" and those given by the participants following the nominal group evaluation under the same theme.

Table 12. Ranking for the reasons why assessment results are not used functionally

1. The families do not accept the results

2. Lack of guidance teachers in the institution

3. The special education teacher does not set aside enough time

4. The administrators do not understand

According to Table 12, the most important and fully agreed item in the nominal group evaluation is "Families do not accept the results." Verbatim quotes taken from teachers' comments with respect to the item rankings agreed on as a result of the nominal group discussion are given below.

..... I think we can put it down to fear of being misunderstood when it comes to parents, or not wishing to upset them; there could be other reasons, we phrase things differently. Maybe it should be said either way but some teachers are exposed to very severe criticism or influence. So, after a time we start asking ourselves who and what am I making the effort for? I have to say that I'm making the effort for my student but when you don't deserve the criticism, you say I shouldn't be so honest, so truthful. Unfortunately, the system teaches us this.(K3) 


\section{What are your suggestions for making child assessment more effective/efficient?}

Table 13 shows the rankings for the items under the theme "Teachers' suggestions to make children's assessment process more effectivelefficient" taken from the transcripts following the focus group discussion and from the participants following the nominal group evaluation.

Table 13. Ranking for making the assessment process more effective and efficient

\begin{tabular}{l}
\hline 1. Pre-service improvements (adding lessons to education programs, lessons being practice-oriented) \\
\hline 2. Improvements for in-service work (improving content, assigning experts, arranging place and time) \\
\hline 3. Assessment tools to be prepared by those in the field, those who are involved \\
\hline 4. Awareness-raising studies on the importance of the subject (to families-administrators) \\
\hline 5. Sharing of academic study results relating to the subject \\
\hline 6. Hiring teachers who love and internalize the profession \\
\hline 7. Creating new methods and techniques for assessment \\
\hline 8. Giving teachers freedom in assessment
\end{tabular}

According to Table 13, the most important and agreed on item in the nominal group evaluation is "Preservice improvements (adding lessons to education programs, lessons being practice-oriented)." Verbatim quotes taken from teachers' comments with respect to the item rankings agreed on as a result of the nominal group discussion are given below.

Let me tell you, my friend, there were few lessons on child assessment at university, and they were not practice-oriented. These can be increased. (K1)

\section{Discussion}

Preschool teachers argue that a multi-aspect approach should be adopted when assessing children's development. When the literature is examined, it is emphasized that many factors such as environment, genetics, and the education process influence a child's development (Berk, 2016; Brooks-Gunn \& Duncan, 1997; McGregor, Cheung, Cuetto, Glewwe, Richter, \& Strup, 2007; Santrock, 2009).

The teachers' opinions here overlap with those in the literature. Furthermore, the teachers emphasized that with respect to multi-aspect child assessment, the child, the family, and the teacher all need to play an active role in the assessment. The teachers stated that the most important recipient of children's assessment results should be the family. The teachers stated that they consider families' socioeconomic status, education, and income levels when assessing children's development. The study made by Trepanier-Street et al. (2001) included teachers' opinions about assessment. According to teachers' opinions, family participation in the assessment process is necessary to make an assessment. The study conducted by Bulur and Tantekin Erden (2017) concluded it was very important that preschool teachers share information from family, other teachers, and experts when assessing children. In this study, preschool teachers believe that the family should be included in the assessment process and that the results are the most important element that needs to be shared. However, one important conclusion of the study was that teachers worry about receiving negative feedback as a result of sharing children's development assessment with families. In the study conducted by Yilmaz Topuz and Erbil Kaya (2016), it was found that in their approach to recognizing and assessing children, some preschool teachers only assess children's negative behaviors. In such situations, assessing only the negative aspects of children's development rather than development as a whole and sharing this assessment with families could lead to conflict between families and teachers.

In this context, when considering the developmental assessment of a child, the most important factor affecting the child's growth and development is the environment in which it lives. This being the case, developmental assessment of a child also involves assessing the child's immediate surroundings. Thus, it can 
be argued that assessment of a child's development not only contributes to the child but also to the family, the education program, and the teacher. Therefore, for families to take an active role in the developmental assessment of children, it is expected that planned and regularly scheduled assessments are made (Erdoğan \& Akkocaoğlu Çayır, 2015; Srinath, Jacob, Sharma, \& Gautam, 2019; Mcmillan, 2007; Shepard, Kagan \& Wurtz, 1998). When the literature is analyzed, it is seen that fundamental to the problems experienced by teachers with families concerning the developmental assessment of their children are the problems of meeting the families when issues are observed, placing much emphasis on complaints and criticism during these meetings, and not implementing or following up the decisions made jointly with the families (Akboy \& İkiz, 2007; Haktanır, 1994).In the study's conclusions, the teachers also argue that they are unable to convince families about their children's development. In this context, it was emphasized that teachers share information about children's developmental issues directly with families only when problems arise. Therefore, it can be said that families are adversely affected in the assessment process making it hard for them to play an effective role. Meisels and AtkinsBurnett (2000) stated that developmental assessment in infancy and early childhood should be made according to some principles. When these principles were examined, many varied sources of information stressed that obtaining information from a person or people who know the child well at specific times and frequently rather than getting momentary or daily updates could be effective in the assessment process. For this reason, families should be included in their children's assessment and in the education process, and be allowed to participate in educational activities (Erickson \& Kurz-Riemer, 1999; Meisels \& AtkinsBurnett, 2000). In this context, one of the most important problems seen in teachers' family participation planning and one of the difficulties in developmental assessment is the high number of children in class. In fact, the developmental assessment process consists of observation. The high numbers of children and the difficulty in following up feedback resulting from sharing developmental assessment with families show the problems of quality in the education given to children.

When the teachers' developmental assessment practices are examined, they stated that used the observation technique the most and that they carried out assessment at various times throughout the education process. When common opinion of assessment time was examined, it was seen that they place more importance on end-of-month assessment because this lets them determine the next month's goals and objectives. When this finding of the study was examined in the light of the literature, Turupcu (2014) found that observation as an assessment tool in preschool education is the most basic of assessment techniques. The study conducted by Taner (2005) examined the opinions of preschool teachers on recognizing and assessing the individual. It was determined that preschool teachers use observation in free-time activities to get to know the child. The study conducted by Diffly (1994) examined preschool teachers' beliefs and views on assessment. When the research results were examined, it was determined that the teachers regarded observation as the primary assessment tool. While the results of that study (Diffly, 1994; Taner, 2005; Turupcu, 2014) are similar to the results of this one, the study conducted by Bulur (2010) found that play was the most important assessment tool used by preschool teachers when assessing child development. In addition, the study by Özkan (2015) stated that teachers mostly used observation, play, conversation, and question-answer techniques while assessing children. In this context, it is understood that the teachers in this study do not use play, conversation, or question-answer techniques of child assessment.

When the literature is examined, the most common and most functional data collection tools that can be used to recognize and evaluate children are seen to be observation records (development observation form), anecdotal records, development checklists and standard tests, development reports, and portfolios (development files) (Epstein, Schweinhart, DeBruin- Paraecki, Robin, \& Robin, 2004; McAfee, Leong, \&Bodrova, 2015; MEB 2006; MEB, 2013). The studies conducted by Yilmaz Topuz and Erbil Kaya (2016) found that while preschool teachers generally use development reports, play observation forms, systematic observation forms, anecdotal records, outcome evaluation forms, and development checklists, very few 
teachers use portfolios to assess child development. According to Sezere (2015), preschool teachers mostly use the outcome assessment form and progress report when assessing children. Pre-school education in Finland was examined in the study conducted by Duran and Taştekin (2020). According to the results of the research, it was determined that teachers used observations, developmental reports, their own experiences and documentation while evaluating children. In this study, preschool teachers stated that they used the portfolio technique after observation, development observation form, development observation report, video recordings, and correspondence when assessing the child. The fact that teachers use the portfolio technique last in child assessment is in line with the conclusions of related studies (Sezer, 2015; Y1lmaz Topuz \& Erbil Kaya, 2016). However, contrary to the results of this study, Özkan (2015) reported that most of the teachers found they used the developmental observation form less when using portfolios to assess children. In addition, all preschool teachers fill out development reports.

When teachers carry out children's developmental assessment, they are expected to use the developmental observation reports currently in use in the preschool education program (MEB, 2006; MEB, 2013). However, the study revealed a critical finding concerning teacher's assessment preparedness levels concluding that they do not know enough about the assessment techniques in the current preschool education program. Furthermore, the fact that assessments remain on paper reveals the difficulties in making developmental assessments in practice. In addition, as there is a monthly developmental assessment form in the preschool education program, teachers consider it critical to do end-of-month assessment because they consider developmental assessment to be a part of the routine monthly assessment (MEB, 2006; MEB, 2013).

According to the study conducted by Yilmaz Topuz and Erbil Kaya (2016), teachers stated that they complained about the need to fill in too many forms, saying it was difficult to allocate time for them, that the class size was too large, and that they had difficulty in communicating with the family. The study conducted by Kang (2013) determined that the teachers could not find enough time for assessment and did not know enough about how to record assessment results. According to the results of the study conducted by Kroeger and Cardy (2006), it was determined that teachers who used documentation as an assessment tool had problems finding time. When the findings of this study are examined, the most common problem faced by teachers during the assessment process is the high number of children in the teaching environment. Teachers also expressed such problems as sharing the results with families, not being able to cooperate with school administrators, not having enough knowledge, having to fill in the forms, and not being able to find time for assessment. The results of this study are similar to the results of a study examined in the literature (Kang, 2013; Kroeger \& Cardy, 2006; Yılmaz Topuz \& Erbil Kaya 2016).

It was determined that the teachers consider their training in children's developmental assessment to be inadequate. In addition, it was determined that during the undergraduate education period, they did not take lessons in child recognition and assessment, nor did they receive in-service training for assessment after starting their teaching careers. It was determined that the education teachers received in developmental assessment included measurement and evaluation. The study conducted by Uzun (2013) examined preschool teachers' self-efficacy with respect to measurement and assessment. The teachers considered themselves competent in this field. However, in this study, preschool teachers state that the measurement and assessment course they take is not sufficient to assess the child. As a matter of fact, the measurement and assessment courses taken by preschool teachers mostly include traditional test methods such as written attendance, verbal exams, and tests. Therefore, alternative methods of child assessment need to be included in detail in measurement and assessment courses. However, this situation is arguable for the purpose of measurement and assessment courses. In this regard, a child recognition and assessment course was added to preschool teachers' undergraduate lessons. It is thought that preschool teachers who take measurement-assessment and child recognition and assessment courses will be able to assess children more effectively. However, the 
teachers in this study group only took measurement-assessment courses in their undergraduate programs. For this reason, they may see the measurement-assessment course as being inadequate to assess the child.

\section{Conclusion and Suggestion}

In light of the study's findings, it can be said that preschool teachers are aware of the meaning and importance of child assessment in preschool period, but deficiencies in both planning and information emerge in practice. Teachers talk about the importance of developmental assessment and identifying children's levels saying that the preschool years are critical. In this regard, they show they are aware of the critical importance of early intervention in developmental assessment and the support training programs that are to be made. In addition, it was determined that parents and teachers need to be aware of the child's level of development and that the type and level of intervention and support for the child is also important. The teachers emphasized that the purpose of assessing children's development is to support their development. When the literature is analyzed (Berk \& Meyers, 2015; Kutlu \& Kaya, 2016; McAfee, Leong, \& Bodrova, 2015; Slavin, 2011) similar conclusions about the importance of developmental assessment are seen.

In this context, it is suggested that for teachers to make qualitative assessments, the pre-service undergraduate programs need to be reviewed, the lessons on child recognition and assessment need to be improved in terms of both quantity and quality, lessons on developmental assessment need to be added, and that more detailed explanations need to be given in the preschool education program to act as signposts and guides for teachers in child recognition and assessment. Teachers can be taught through practice by developing projects aimed at child recognition and assessment. For the child-assessment process to be more qualified, class sizes need to be small. Therefore, the necessary planning should be made to increase the number of preschool education institutions. 


\section{REFERENCES}

Akboy, R., \& İkiz, F. E. (2007). Psikolojik danışma ve rehberlikte çă̆daş bir anlayış: Yaşamla iç içe yaşam boyunca. Ankara: Nobel Yayıncilı.

Akyüz, E. (2000). Ulusal ve uluslararası hukukta çocuk haklarının ve güvenliğinin korunması. Ankara: Milli Eğitim Basım Evi.

Allen, K. E., \& Cowdery, G. E. (2009). The exceptional child: Inclusion in early childhood education. 6th ed. New York: Thomson Delmar Learning.

Ariasian, P.W.(1994). Classroom assessment (2nd ed.). New York: McGraw Hill inc.

Ausubel, D. P., Ives, S. W., \& O'Sullivan, E. V. (1980). Theory and problems of child development. 3d ed. New York: Grune \& Stratton.

Berk, L. E. (2016). Infants and children: Prenatal through middle childhood. Boston: Pearson.

Berk, L. E., \& Meyers, A. B. (1996). Infants, children, and adolescents. USA: Pearson.

Bowling, A. (2002). Research methods in health: Investigating health and health services. Philadelphia, PA: McGrawHill House.

Bowman, B., Donovan, M., \& Burns, M. (2001). Eager to learn: Educating our preschoolers. Washington, DC: National Academy Press.

Bredekamp, S. (2014). Effective practices in early childhood education: Building a foundation. Upper Saddle River, NJ: Pearson.

Brooks-Gunn, J., \& Duncan, G. J. (1997). The effects of poverty on children. The Future of children, 7(2), 55-71.

Buldu, M. (2010). Do They walk the talk: An examination of turkısh in-service early childhood teachers' assessment practıces. Unpublished Master Dissertation. Middle East Technical Unıversity, Ankara.

Buldu, M., \& Tantekin- Erden, F. (2017). An Investigation of Turkish Early Childhood Teachers' Self-Reported Beliefs and Practices Regarding Assessment. Journal of Education and Future, 11, 29-49.

Diffily, D. L. (1994). Early childhood educators' beliefs and practices about assessment. Unpublished Doctoral Dissertation. University of North Texas, Texas.

Dunphy, E. (2010). Assessing early learning through formative assessment: Key issues and considerations. Irish Educational Studies, 29 (1), 41-56.

Duran, M., \& Taştekin, A. N. (2020). Finlandiya erken çocukluk eğitimi. Kahramanmaraş Sütçü İmam Üniversitesi Sosyal Bilimler Dergisi, 17 (2), 600-624.

Edmunds, H. (2000). The focus group research handbook. New York: McGraw-Hill.

Epstein, A. S., Schweinhart, L. J., DeBruin-Parecki, A., \& Robin, K. B. (2004). Preschool assessment: A guide to developing a balanced approach. Preschool Policy Matters, 7, 1-2.

Erdoğan, T., \& Akkocaoğlu, N. (2015). Dramada ölçme ve değerlendirme. Ankara: Eğiten Kitap.

Erickson, M. F., \& Kurz-Riemer, K. (1999). Strengthening family support networks. Ch. 5 in Infants, Toddlers, and Families: A Framework for Support and Intervention. New York: The Guilford Press.

Gander, J. M., \& Gardiner, W. H. (2015). Çocuk ve ergen gelişimi. edited by Bekir Onur. Ankara: İmge.

Gober, S. Y. (2002). Six simple ways to assess young children. New York: Delmar.

Haktanır, G. (1994). Çocuğun ruh sağlığında aile ve okulun önemi. Okul Öncesi Ĕ̆itimi Dergisi, 47, 9-14. 
Harlen, W. Gipps, C., Broadfoot, P., \& Nuttall, D. (1992). Assessment and the improvement of education. The curriculum journal, 3(3): 215-230.

Kang, J. (2013). Thoughtful early childhood teachers: Documentation as part of teaching. Published Doctoral Dissertation. University of Illinois.

Kroeger, J., \& Cardy, T. (2006). Documentation: A hard-to-reach place. Early Childhood Education Journal, 33(6), 389-398.

Krueger R. A., \& Casey, M. A. (2009). Focus Groups: A Practical Guide for Applied Research. 4th ed. Thousand Oaks, CA: Sage Publications.

Krueger, R. A. (1998). Moderating focus groups. California: SAGE.

Kutlu, M., \& Kaya, A. (2016). Bireyi tanıma ve bireyi tanıma teknikleri. In Psikolojik Danışma ve Rehberlik edited A. Kaya, 197- 302. Ankara: Anı Yayıncilık.

MacPhail, A. (2001). Nominal group technique: A useful method for working with young people. British Educational Research Journal, 27(2), 161-170.

McAfee, O., Leong, D. J., \& Bodrova. E. (2015). Assessing and guiding young children's development and learning. 6th ed. Boston: Pearson Education.

Mcmillan, H. J. ( 2007). Classroom assesment: principles and practices for effective standarts-based instruction. Boston, MA: Pearson/Allynve Bacon.

MEB (Milli Eğitim Bakanlığı) [Ministry of National Education]. (2006). Okul Öncesi Eğitim Programı (36-72 aylık çocuklar için). Ankara: Temel Eğitim Genel Müdürlüğü

MEB (Milli Eğitim Bakanlığı) [Ministry of National Education]. (2011). Çocuk Gelişimi ve Eğitimi, Çocukları Tanıma Teknikleri. Ankara.

MEB (Milli Eğitim Bakanlığı) [Ministry of National Education]. (2013). Okul Öncesi Eğitim Programı (36-72 Aylık Çocuklar İçin). Ankara.

MEGEP (Mesleki Eğitim ve Öğretim Sisteminin Güçlendirilmesi Projesi) [Project on Strengthening the Vocational Education and Training System]. (2006). Çocukları Tanıma Teknikleri. Ankara: Milli Eğitim Basımevi

Meisels, S. J., \& Atkins-Burnett, S. (2000). The elements of early childhood assessment. In Handbook of Early Childhood Intervention. 2nd. Ed. edited by J.P. Shonkoff and S.J. Meisels Cambridge, UK: Cambridge University Press.

Merriam, S.B. (2013). Qualitative research a guide to design and implementation. New York: John Wiley \& Sons Inc.

Miles, M. B., \& Huberman, A. M. (1994). Qualitative data analysis. Thousand Oaks, CA: Sage Publication.

Mindes, G. (2003). Assessing young children. Columbus, Ohio: Merrill.

Neuman, W. L., \& Robson, K. (2014). Basics of social research. Toronto: Pearson Canada

Özkan, F. (2015). Okul öncesi eğitimde değerlendirme sürecine yönelik aile-öğretmen görüş ve beklentilerinin incelenmesi. Yayınlanmamış Yüksek Lisans Tezi. Hacettepe Üniversitesi, Ankara.

Santrock, J. W. (2012). A topical approach to life-span development. 6th ed. New York: McGraw-Hill.

Sezer, C. (2010). Okul öncesi öğretmenlerinin ölçme değerlendirmeyi kullanma düzeylerinin belirlenmesi. Yayımlanmamış Yüksek Lisans Tezi. Çanakkale Onsekiz Mart Üniversitesi, Çanakkale. 
Shaughnessy, M. F., \& Greathouse, D. (1997). Early childhood assessment. recent advances. Early Child Development and Care, 130(1),31-39.

Shepard, L., Kagan, S., \& Wurtz, E. (1998). Principles and recommendations for early childhood assessments. Washington, DC: National Educational Goals Panel.

Slavin, R. (2011). Educational psychology: Theory and practice. Boston: Pearson Education.

Snow, C. E., \& Van Hemel, S. B. 2008. Early childhood assessment: Why, what and how. Report of the committee on developmental outcomes and assessment for young children for the national research council. Washington, DC: National Academies.

Srinath, S., P. Jacob, E. S., \& Gautam, A. (2019). Clinical practice guidelines for assessment of children and adolescents. Indian journal of psychiatry, 61(Suppl 2), 158-175.

Stake, R. (1995). The art of case study research. Thousand Oaks, CA: Sage Publications.

Taner, G. (2005). Bireyi tanıma tekniklerinin okul öncesi eğitim kurumlarında uygulanmasına ilişkin öğretmen görü̧̧lerinin incelenmesi. Yayımlanmamış Yüksek Lisans Tezi. Selçuk Üniversitesi, Konya.

Telzrow, C. F. (1991). The school psychologist's perspective on testing students with traumatic brain injury. The Journal Of Head Trauma Rehabilitation, 6(1), 23-34.

Trepanier-Street, M. L., McNair, S., \& Donegan, M. M. (2001). . Journal of Research in Childhood Education, 15(2), 234-241.

Turupçu, A. (2014). Observation as an assessment tool in early childhood education: a phenomenological case study of teacher views and practices. Published Master's Thesis, Middle East Technical University, Ankara.

Uzun, Ü. (2013). Farkl türlerde eğitim hizmeti veren okul öncesi eğitim kurumu öğretmenlerinin ölçme ve değerlendirme yeterliliklerine ait görüşleri. Yayımlanmış Yüksek Lisans Tezi. Yeditepe Üniversitesi, İstanbul.

Varga-Atkins, T., \& McIsaac, J. (2011). Using the Nominal Group Technique with clickers to research student experiences of e-learning: A project report. Written for the ELESIG Innovations in Education and Teaching International 11 Small Grants Scheme. Liverpool: University of Liverpool. Retrieved from http://slidesha.re/1iHXXgG

Varga-Atkins, T., McIsaac, J., \& Willis, I. (2017). Focus group meets nominal group technique: an effective combination for student evaluation?. Innovations in Education and Teaching International, 54 (4), 289-300.

Wilson, V. (1997). Focus Groups: A Useful Qualitative Method for Educational Research?. British Educational Research Journal, 23, 209-224.

Yıldırım, A., \& Şimşek. H. (2013). Sosyal bilimlerde nitel araştırma yöntemleri. Ankara: Seçkin Yayınevi.

Yılmaz Topuz, G., \& Erbil Kaya, Ö. M. (2016). Okulöncesi eğitim öğretmenlerinin çocukları tanıma ve değerlendirme amaçlı yapılan çalışmalara ilişkin görüşleri. Anadolu Journal of Educational Sciences International, 6(1), 27-62.

Yin, R. (2009). Case study research: Design and methods, fourth edition. Thousand Oaks, CA: Sage Publications. 